\title{
THE SEARCH FOR CLASSIFIED INFORMATION - THE REAL FIGHT IN THE COLD WAR
}

\section{Laviniu BOJOR}

\author{
“Nicolae Bălcescu" Land Forces Academy, Sibiu, Romania \\ laviniu.bojor@gmail.com
}

\begin{abstract}
The effort to get classified information from inside the adverse camp was the main objective of both super powers involved in the Cold War. Both the USA and the USSR tried, by all means at their disposal, to be one step ahead of the opponent by knowing their capabilities and adverse plans. This paper approaches the manner in which intelligence-gathering specialized structures from both camps were involved in collecting data and intelligence to win the information battle during the Cold War.
\end{abstract}

Keywords: COLD WAR, tradecraft, technology, HUMINT, OSINT, SIGINT, GEOINT,

\section{Introduction}

The end of the Second World War was supposed to represent the beginning of a period of peace and quiet for the peoples in Central and Eastern Europe. The violence and horrors of the war caused by the aspirations of the Nazi totalitarian regime stopped, but the ideology and the ascension of the Soviet Communist Party, which failed to withdraw from the "liberated" territories, led to the division of Europe and of the entire world into two poles of power. The pulling of the Iron Curtain began with the division of Germany and the West Berlin blockade, culminating in the formation of state blocs, allied on the basis of political-military treaties. The Western states, led by the USA, joined their forces in 1949 under NATO's security umbrella, while the USSR and its new "satellite states" signed the Warsaw Treaty in 1955. These changes on the political map of the world meant the transition from the TOTAL WAR to the COLD WAR, which did not materialize in a direct armed confrontation between the two political- military blocs, but in a permanent search for enemy's secrets. The main actors were not the armed military forces but the agencies specially developed to collect actual and timely information. In this paper we will analyze the specific COLD WAR operational environment in which intelligent assets acted and the factors that led to the change of the American tradecraft from collecting information using the human factor to information collection based mostly on technology.

\section{Communism versus Democracy or Closed versus Open society}

The Cold War was not just a war of espionage agents. It was a struggle between the communist ideology, widespread and imposed by the Soviets, and the democratic one promoted by the capitalist countries. The Communist system adopted, from the very beginning, the force, the coercion, the threat, the blackmail or the bribe (especially in territories outside its area of influence). Intimidation through violence was practiced not only on its own citizens but also on the 
diplomatic staff, in order to deter possible espionage actions. Intimidation was also applied to Western allies to keep them out of the communist bloc. This materialized in the partial demobilization of the army used against the Nazi regime and in keeping significant military forces on the territory of East Germany and near the Iron Curtain. In the period 1947-48, US analysts' estimates indicated a 10: 1 ratio of forces in favour of the Soviets: "105 rifle divisions (of which
40 were motorised), 35 mechanised divisions, 25 armoured, and 10 cavalry. They were presumed to have a disposition that would enable them to attack western interests at many points along the periphery of Soviet power"[1]. To these, we can add "56 divisions possessed by the Eastern European allies of the Soviet Union"[2], which leads to an estimated number of divisions of over 230:

Table 1 Soviet and Allied forces in the beginning of the Cold War

\begin{tabular}{|c|c|c|c|c|}
\hline \multicolumn{2}{|c|}{ Soviet (starting with 1947) } & & \multicolumn{2}{|c|}{ Western Allies (1950) } \\
\hline Area & Divisions & \multirow{9}{*}{ vs } & Divisions & Area \\
\hline Soviet Occupied Europe & 35 & & 11 & Western Europe \\
\hline $\begin{array}{c}\text { Western Frontier Military } \\
\text { Districts }\end{array}$ & 49 & & \multirow{6}{*}{9} & \multirow{6}{*}{$\begin{array}{c}\text { Indochina, Indonesia, } \\
\text { Belgian Congo, } \\
\text { Malaya, } \\
\text { USA }\end{array}$} \\
\hline West Central Military Districts & 20 & & & \\
\hline Caucasus Military Districts & 21 & & & \\
\hline Middle Asia Military Districts & 19 & & & \\
\hline Far East (Incl. 4 in Manchuria) & 31 & & & \\
\hline Soviet allies & 56 & & & \\
\hline TOTAL & 231 & & 20 & TOTAL \\
\hline
\end{tabular}

The same sources show the fact that the Soviets "could put 320 divisions in the field within 30 days of the start of mobilisation, and that this could be increased to 470 divisions and 12 million troops after one year of mobilisation"[3]. On the other hand, in the summer of 1950, "NATO possessed fewer than 20 divisions of troops world-wide, and only 11 in the Western Europe", so a 10:1 ratio of forces in favor of the Soviets, and "These American personnel were primarily involved in "de-nazification" and the maintenance of law and order, and did not possess the armour or air power that would have made them capable of taking on a Soviet force" [4].

But NATO counterbalanced these massive conventional forces through the nuclear capabilities available at the time to the US, the effects of the bombs at Hiroshima and Nagasaki discouraging any intention to expand the communist bloc outside the iron curtain.

America and its allies focused on economic growth and chose to recruit human assets by offering freedom or money for the information gathered behind the iron curtain. They did not resort to the violence characteristic to communist secret services, these inhumane and immoral practices being initially rejected by the democratic spirit that puts human rights on the first place. Immediately after WW2, the USA was determined to return to its old neutral actor status on the global security scene and to continue its economic development at the Atlantic Ocean shelter. But some events, such as the 1949 nuclear power loss or the 1950s Korean communist expansion, persuaded it to rethink its intelligence strategy. 


\section{CIA vs KGB. Inception.}

The closed society of the Soviet Bloc applied strict censorship on all public sources specific to Open Source Intelligence-OSINT (government reports, libraries, newspapers, radio-TV, press conferences etc) which made it impossible for US to exploit these overt sources, as they did not bring any valuable intelligence. On the other hand, the Soviets considered true intelligence (razvedka) only the information received from secret informants and undercover agents.

"When the Russians want to know the number of bombers in the air force of a potential adversary, they get the figure, not by doing library research on the productive capability of airplane plants or assembling educated guesses and rumors, but by asking their secret informers within the foreign air force or war ministry and by stealing the desired information from government files"[5]. Given these facts, both parties formed tradecraft organizations and intelligence departments covert sources oriented.

During the Second World War, the USA had the Office of Strategic Services (OSS), department responsible for "spying, sabotage, intercepting communications, or conducting paramilitary actions behind enemy lines"[6]. After the war, President Truman appreciated the nuclear capabilities held by the US as sufficient to win any armed conflict. He considered that the intelligence activity was no longer justified in peacetime and signed, in September 1945, the OSS dismantling decree. In the period immediately following the end of the war, 1945-1947, the US intelligence activity was limited to the structural reorganization of the new intelligence departments divided between state and war departments. Moreover, the US did not consider its USSR ally to be an immediate threat, concentrating its subsequent efforts on the search and punishment of Nazi leaders, or on recruiting famous scientists or technicians like the ones on Osenberg
List[7]. Stalin's subsequent actions, marked in particular by his refusal to withdraw his troops from the territories of the Eastern European states and by the consolidation of Soviet power by imposing communist ideology in Eastern Europe, were the signal that brought USSR into the spotlight of US intelligence. The foundation of the Central Intelligence Group (CIG) and the inclusion of the SSU core in it led to the formation of the Central Intelligence Agency CIA, in 1947, with the primary mission to predict the Soviet behaviour.

The CIA's delayed start in the struggle for informational supremacy in Central and Eastern Europe enabled the main opponent, the Soviet State Security body (WW2 and the political changes at the highest level, made the Soviet intelligence services exist under several organizations until 1954 when they were assembled as a well-known Committee for State Security - KGB) to more easily develop their information collection networks and be better prepared for this spy confrontation. In the early years of the Cold War, the work of US secret services in Germany and Eastern Europe, mainly carried out by OSS residues, was almost null. It was mainly based on collaboration with European intelligence agencies, most of the reports sent to Washington being taken over by French, Italian or English agents. The American HUMINT capabilities that were not withdrawn from Europe did not rise to the Soviet level. Lack of experience, naivety, incompetence, corruption, or the blackmail practiced by the opponent are factors that allowed the KGB to take over the initiative and, subsequently, intelligence supremacy in the early part of the Cold War.

\section{Human based intelligence collection Human Intelligence (HUMINT), defined} as the category of intelligence derived from information collected and provided by human sources, represented, as we are showing in this paper, the source that offered access to the biggest secrets of the 
enemy and caused the greatest damage, both to the Eastern states and the communist bloc.

HUMINT is collected through:

- Clandestine acquisition of photography, documents, and other material

- Overt collection by people overseas

- Debriefing of foreign nationals and U.S. citizens who travel abroad

- Official contacts with foreign governments. [9]

Clandestine acquisition of photography, documents, and other material was a battle clearly won by Soviet secret services. The pro-communist ideology or feelings at the beginning of the Cold War made the Soviets quickly overcome the nuclear disadvantage due to Manhattan Project leakage[10], and even impose their informational supremacy by infiltrating key supporters in allied government structures[11]. The heavy start and the lack of experience of the Americans, the infiltration of British secret services even during the Second World War or the "reorganization" stage the French secret services were in, were the main elements that allowed the Soviet secret services reject any attempt to penetrate the Eastern Bloc.

The operations carried out by both sides aimed at identifying and exploiting the motivation to succeed in recruiting assets: money, ideology, revenge, romance, ego or even blackmail. In this respect, person-toperson queries and discussions or other methods of surveillance sought to achieve the exact profile of that person.

In the Soviet Bloc, any defector who, for family or other reasons, was returning inside the Iron Curtain was forced by the security forces to declare that he had been subjected to ill-treatment or other inhumane acts which the West applies to all Communists. The cases were strongly publicized by the state in order to deter the actions of those who intended to flee to the West.

As for the diplomatic corps, we also have different approaches to Human intelligence tradecraft. If the recruitment of diplomatic staff was attempted in the West by offering financial advantages, in the Communist bloc this was, from the start, intimidated by permanent surveillance. The closed society specific to the Eastern Bloc and the political body involving in the battle all the resources at its disposal, also led to the use of less moral methods. The use of seduction to obtain information represented a basic method of all agencies in the satellite communist states. These methods called "honey trap" were able to get information by recruiting American diplomats or even American security staff hit by Cupid's false arrows[12]. Even though most of these actions involved the use of women, code name "swallow", they proved equally effective if the men, the code name "raven", were used for homosexual exploitation urges or as a honey pot for women recruitment involving sexual seduction. The declassification of some CIA files shows that this intelligent tradecraft, a very costeffective way to access secrets, was heavily used by Markus Wolf, the mastermind behind the East-German service STASI. „Because of the war, many women of marrying age had taken jobs in business, government, parliament, the military, and the intelligence services in West Germany, and they often had access to highly classified government secrets. With the shortage of eligible men-another consequence of the war-single West German women, eager for male companionship, became frequent targets for East German male spies who were only interested in them for one thing: secrets. These men from the East earned the nickname "Romeo Spies".[13]

Moreover, any citizen who was talking with the embassy staff was monitored and subjected to interviews stating whether he had been recruited or whether he could be used as a double agent.

To stop "volunteer" 'walk-in' recruitment, the secret services of the Soviet bloc used extensively the method of luring the 
opponent by using agents called "dangles"[14]. The intoxication with these false secret agents compromised the US intelligence gathering networks that originally fell into the $\mathrm{KGB}$ trap and gradually uncovered allied networks. This Humint tradecraft used by the Soviets made the allied services, especially the American ones, very reluctant to those who were offering their services, and was sometimes one step away from losing access to important human sources like Tolkachev.

The highly superior Soviet tradecraft, which maintained its sources even during the WW2 and during the alliance with the Western countries, made the beginning of the COLD WAR be marked by the intelligence superiority of the Communist Humint. All attempts of the allied services to infiltrate human agents inside the secret networks of the communist satellite states were exposed by counterintelligence services due to information leakage from key persons such as Kim Philby who became head of the counter-espionage department of SIS (MI 6). Allied secret agencies fought blindfolded and against an unscrupulous adversary. The uncertainty about the capabilities and intentions of the WARSAW Pact, amplified by the Soviet nuclear tests of 1949, made NATO and, in particular, the US reconsider its military budget and invest in science and technology to obtain information by means other than the human ones.

\section{Technology based intelligence collection}

Humint's failure made NATO concentrate its effort on the technological advantage it had over the Soviets. For this, in 1948, the CIA created its Office of Scientific Intelligence (OSI), which was incorporated into the Directorate of Science \& Technology in 1963. In line with the CIA, the DS\&T mission was "to solve our nation's most pressing intelligence problems"[16] They used their expertise to address the most important intelligence issues "with effective targeting, bold technology and superb tradecraft' [17] . Their main mission was to adapt, develop and operate state-of-the art technological systems capable of gathering, processing and analyzing information from all operational environments. The land ones were used in the ongoing effort of intercepting and decoding adverse messages. For the air there were used airplanes which were made to fly at high altitudes, and spy satellites with highresolution photographic equipment were launched into the cosmos. Military science and technology filled the marine space with nuclear submarines, and the information environment changed society forever by creating the Arpanet network, which lay the foundations of the current global Internet network.

The efforts of the American technology development were first directed towards Signals intelligence (SIGINT). SIGINT, defined as a ,collection and exploitation of signals transmitted from communication systems, radars, and weapon systems as signals"[18] was intelligence tradecraft that brought outstanding results to the Allies during WW2, by deciphering the Nazi codes of Enigma.

SIGINT consists of:

- Communications Intelligence (COMINT) - technical and intelligence information derived from intercept of foreign communications.

- Electronic Intelligence (ELINT) information collected from systems such as radars and other weapons systems.

- Foreign Instrumentation Signals Intelligence (FISINT) - signals detected from weapons under testing and development.[19]

The Venona Program started in 1943 with the mission ,to examine and exploit Soviet diplomatic communication"[20]. It managed to break the KGB encryption codes, and the revealed information, by intercepting and decrypting thousands of messages, told allies that hundreds of 
officials from the Foreign Ministry or even the White House were working for the Soviet intelligence. On the long list of those who collaborated with the USSR, there was also Harry Lloyd Hopkins, a close advisor of President Franklin Roosevelt.

The Venona Project was able to identify the leakage of nuclear secrets in the Manhattan Project immediately after the 1949 Soviet Nuclear Tests. Using Venona, the Western Bloc had access to data on the capabilities of the Soviet armed forces deployed in Central Europe.

The Venona project was recently continued by the bolder ECHELON program, created in the late 1960 s to monitor the military and diplomatic communications of the Soviet Union and its Eastern Bloc. Using it in combination with other software suites offers unlimited capabilities for global mass surveillance, for which it was widely criticized, as it was considered that it ,invades privacy, limits liberty and violates the Fourth Amendment of the US Constitution" [22].

The Berlin tunnel was another ambitious operation of the US-British secret services during the Cold War. They dug a tunnel 1,476 feet long and connected themselves to telephone and telegraph communications between Moscow, Warsaw, and Bucharest. „The success in numbers includes:

- 50,000 reels of tape

- 443,000 fully transcribed conversations (368,000 Soviet and 75,000 East German)

- 40,000 hours of telephone conversations

- 6,000,000 hours of teletype traffic

- 1,750 intelligence reports".[23]

Interceptions of Soviet military communications also recorded submarine actions such as the Ivy Bells Operation, which managed to connect a 6 tons wiretap device to the cable on the Sea of Okhotsk.

The technological development initiated to provide secret agents with miniature equipment to be hidden and used secretly (cameras, interception and message transmission systems, encryption and decryption equipment, etc.) was only the beginning.

The realization of U2 high-altitude reconnaissance aircraft revealed to the Allies a series of anti-ballistic missile facilities, which became the priority of the SIGINT effort. ELINT aerial platforms were designed to intercept and listen to the enemy's signals outside the enemy borders, and the next step was to overcome space barriers and launch artificial satellites.

The first move belonged to the Soviets, on 4 October 1957, with the launch of SPUTNIK 1, which mobilized the US government and agencies for the space conquest race. They managed to launch their first satellite containing an ATHOStype receiver in low Earth orbit on 22 June 1960, having the mission of intercepting Soviet radar signals. "The very first SIGINT satellites, launched in 1960, were intended to detect and locate air defense radars, to determine the electronic order of battle (EOB, which listed the types and locations of Soviet defense system radars), and thus to assist American bombers to pass through Soviet defenses to military targets in the event of war". The advantage of the SIGINT satellite equipped with "antennas, receivers, and, sometimes, tape recorders" was it" transmitted its findings by radio link in realtime or shortly after passing over the target area" but the challenges were many because "The targets of the SIGINT systems were the actual radio signals radiated by Soviet transmitter equipment, which meant that the satellites had to be in the right place, looking in the right direction, tuned to the right frequency, at the very time the Soviet transmitters were on the air".

The cosmos became the new Cold War arena and each party has allocated enormous financial budgets for space conquest. The race was won by the United States in 1969 with Neal Amstrong's landing on the moon.

Scientific and technological development allowed passing from simple imagery 
intelligence to complex Geospatial Intelligence (GEOINT). "The term "geospatial intelligence" means the exploitation and analysis of imagery and geospatial information to describe, assess, and visually depict physical features and geographically referenced activities on the earth". [26]

„Consists of:

- Imagery - a likeness of any natural or man-made feature, as well as its location.
- Imagery Intelligence (IMINT) information derived through interpreting imagery.

- Geospatial Information - information that identifies a natural or constructed feature on Earth by its geographic location and other characteristics"[27]. The limitation to interpreting photographs collected by airplanes, drones, or balloons was overcome with the launch of satellites in orbit as shown in Figure 1[28].
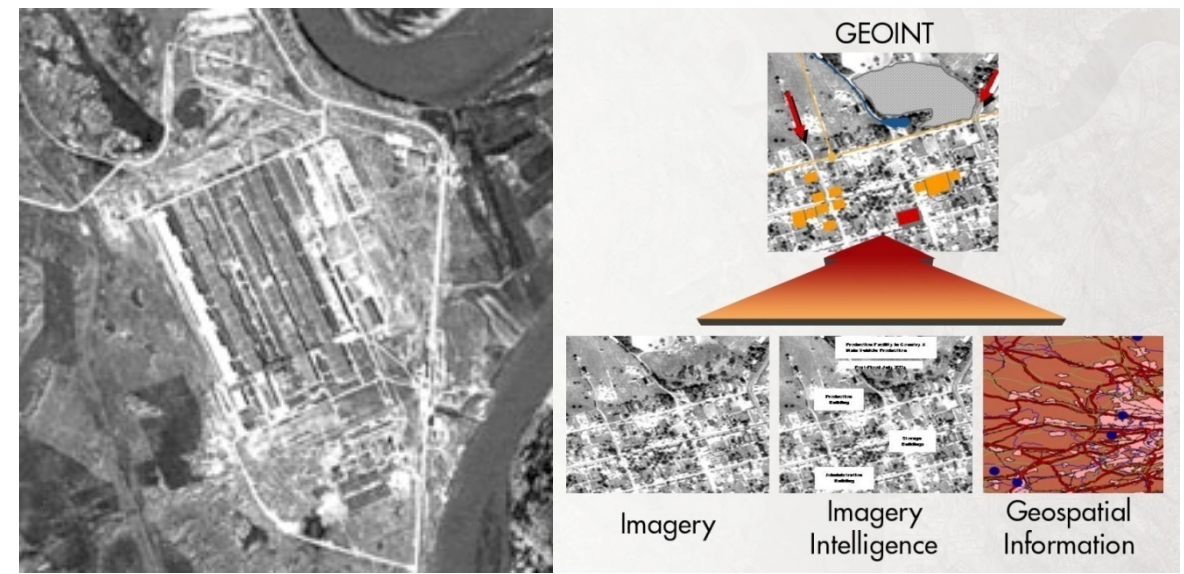

Figure 1: Evolution from Imagery intelligence to geospatial intelligence

GEOINT allows three-dimensional collection and analysis of the Earth, providing information about natural (mountains, valleys, hills, etc.) or man made obstacles (buildings, streets, bridges, etc.) without endangering human assets. GEOINT has become indispensable today due to the real-time information it provides about the exact location of strategic nuclear facilities, human terrain data, environment, community structures, healthcare, mass media, etc.

Measurement and Signature Intelligence (MASINT) is scientific and technical intelligence information obtained by quantitative and qualitative analysis of data (metric, angle, spatial, wavelength, time dependence, modulation, plasma, and hydromagnetic) derived from specific technical sensors for the purpose of identifying any distinctive features associated with the source, emitter, or sender and to facilitate subsequent identification and/or measurement of the same.[29]

This field of collecting information with the help of sensors has been used since the start of the Cold War, in 1949, when the filters mounted on the American planes detected the radioactive traces of the first nuclear tests carried out secretly by the Soviets. The need for national security intelligence (missile launches warning, detection of aircraft and submarines, target recognition, intruder detection, fratricide prevention and any other signature based military system) led to the development of a complex system of sensors capable of replacing human eyes and ears.

Today MASINT is present in all scientific and technological fields and it includes:

- Radar Intelligence (RADINT)

- Acoustic Intelligence (ACOUSTINT)

- Nuclear Intelligence (NUCINT)

- Radio Frequency/Electromagnetic Pulse Intelligence (RF/EMPINT) 
- Electro-optical Intelligence (ELECTROOPTINT)

- Laser Intelligence (LASINT)

- Materials Intelligence

- Unintentional Radiation Intelligence (RINT)

- Chemical and Biological Intelligence (CBINT)

- Directed Energy Weapons Intelligence (DEWINT)

- Effluent/Debris Collection

- Spectroscopic Intelligence

- Infrared Intelligence (IRINT).[30]

\section{Conclusions}

Even though the Soviets proved their superiority in the HUMINT field from the beginning, winning all the COLD WAR information battles in the early years, Western allies have counterattacked through information gathering based on advanced technology. But this lack of onthe-ground sources often made the West have access to surface information, more quantitative and non-qualitative. Most intelligence estimates overvalued the real capabilities in the economic and military field, as they failed to predict the collapse of the Soviet bloc. At the same time, the penetration of the highest level military and political structures made many information gathering efforts be revealed or those operations be used by the Soviets for ample misinformation actions. The Berlin tunnel, which involved enormous financial efforts, hundreds of translators and analysts, was uncovered by George Blake, a KGB penetration of the British Secret Intelligence Service.
The Venona project, which successfully succeeded in decrypting the communications of the Eastern bloc and identifying the extent of Soviet penetration into the allied structures, was revealed by William Weisband, an American cryptanalyst and NKVD agent. The missile crisis was not won by the IMINT or SIGINT supremacy of the nuclear facilities prepared on Cuba island but by the information provided by Oleg Penkovsky, and the device for intercepting Russian underwater communications, located on the bottom of Okhotsk Sea, was disclosed by Ronald Pelton, a veteran of the National Security Agency (NSA).

Even though they used different approaches, both secret services of the two great powers achieved remarkable results in access to classified information. The final outcome of the confrontation was not decided by secret intelligence services, and we cannot say that the CIA won the fight against the Soviet KGB following the collapse of the Communist Bloc. What we can say is that democracy led to the Communist collapse, and many of the advances in science and technology are currently used in society, even if they were invented strictly to achieve military goals. What we can state is that the end of Cold War also had winners. These were the Central and Eastern European satellite countries, including Romania, who truly won their sovereignty and came out of the rule of a totalitarian, communist, violencebased system that proved to be one that not only lacks rights but it is also economically ineffective.

\section{References}

[1] Raymond Ojserkis, "The United States \& the beginning of the Cold War arms race", p. 79, accessed on http://etheses.lse.ac.uk/2607/1/U615556.pdf

[2] idem

[3] idem

[4] idem p.84

[5] https://www.cia.gov/library/center-for-the-study-of-intelligence/kentcsi/vol7no2/html/v07i2a05p 0001.htm 
[6] https://www.encyclopedia.com/history/united-states-and-canada/us-history/officestrategic-services

[7] Paperclip Operation managed to recruit over 1600 German scientists, such as Wernher von Braun, who had an important contribution to the National Aeronautics and Space Administration. Article Willkommen, 'Operation Paperclip, ' by Annie Jacobsen, accessed on https://www.nytimes.com/2014/03/02/books/review/operation-paperclipby-annie-jacobsen.html

[8] Intelligence Community Directive number 304 -Human Intelligence, p.6, accessed on https://fas.org/irp/dni/icd/icd-304-2008.pdf

[9] https://www.cia.gov/news-information/featured-story-archive/2010-featured-storyarchive/intelligence-human-intelligence.html

[10] Nuclear spy ring consists of Julius and Ethel Rosenberg, Harry Gold, Klaus Fuchs, David and Ruth Greenglass

[11] Kim Plilby

[12] https://spywriter.wordpress.com/2011/02/12/using-sex-in-espionage/

[13] https://www.cia.gov/news-information/featured-story-archive/2018-featured-storyarchive/romeo-spies.html

[14] Dangle - A person sent by the intelligence agency of his or her own country who approaches an intelligence agency in the hope of being recruited as a spy so as to allow a double agent operation for the purpose of intelligence collection or disinformation, https://www.spymuseum.org/education-programs/news-books-briefings/language-ofespionage/

[15] Matt Schudel, Cold War Spy Tale Came to Life on the Streets of Moscow, Washington Post Staff Writer Sunday, April 20, 2008, accessed on

http://www.washingtonpost.com/wpdyn/content/article/2008/04/19/AR2008041902071_pf.html

[16] https://www.cia.gov/offices-of-cia/science-technology

[17] idem

[18] https://www.cia.gov/news-information/featured-story-archive/2010-featured-storyarchive/intelligence-signals-intelligence-1.html

[19] idem

[20] https://web.archive.org/web/20140628021144/http://www.nsa.gov/public info/declass/v enona/

[21] https://www.nsa.gov/about/cryptologic-heritage/historical-figurespublications/publications/coldwar/assets/files/venona story.pdf

[22] Talitha Nabbali "Going for the throat: Carnivore in an ECHELON world - Part II', https://doi.org/10.1016/S0267-3649(04)00018-4

[23] https://www.cia.gov/news-information/featured-story-archive/the-berlin-tunnelexposed.html

[24] http://www.governmentattic.org/19docs/NRO-SIGINTsatStory 1994u.pdf p. 5

[25] idem p. 6

[26] http://codes.findlaw.com/us/title-10-armed-forces/10-usc-sect-467.html

[27] https://www.cia.gov/news-information/featured-story-archive/2010-featured-storyarchive/geospatial-intelligence.html

[28] https://www.cia.gov/library/center-for-the-study-of-intelligence/csi-publications/csistudies/studies/vol48no2/article01.html

[29] https://fas.org/irp/program/masint.htm

[30] idem 